\title{
Terorisme Global
}

Shohibul Anshor Siregar

|Siyono meninggal | Densus 88 digugat | Muhammadiyah menuntut keadilan | Muhammadiyah menuntut Pancasila sebagai dasar bagi pelaksanaan perang terhadap teroris dan wajib dilakukan komprehensif | Jangan sekali-sekali menyudutkan Islam Indonesia yang andilnya sangat-sangat besar itu, dengan isyu teroris yang dikendalikan asing | Itu harapan dan permintaan Muhammadiyah |

Perang terhadap terorisme (war on terrorism) yang memaksa keterlibatan banyak Negara di dunia, dan terkadang secara kualitatif maupun kuantitatif mereduksi tajam kedaulatan Negara-negara yang dilibatkan dalam kerjasama, apalagi jika negara itu Negara lemah, terutama setelah peristiwa yang lebih dikenal dengan 911, begitu dahsyat untuk diabaikan dalam kajian hubungan internasional pasca perang dingin. Tentu saja pemupukan dominasi Negara adidaya dalam proses itu, yang sering terabaikan, juga sangat menarik. Aksi-aksi penistaan terstruktur satu kepada lain Negara atau penduduk Negara, dengan mandat pemerintahan internasional pula, tak dapat diabaikan.

Setelah kejadian 911, arah yang begitu jelas memusuhi Islam begitu kuat. Ini memang aneh. Definisi yang tidak ambigu dan dapat terterima oleh seluruh masyarakat internasional tentang terorisme itu sendiri sulit didapatkan hingga kini, termasuk oleh PBB sendiri, tetapi ada keinginan besar untuk memaksakan kehendak oleh kekuatan internasional. Cukup popular pemahaman saat ini di seluruh dunia bahwa tidak semua muslim teroris, tetapi semua teroris adalah muslim. Ini bertentangan dengan fakta sepanjang sejarah, dan cenderung menodai Islam dan pemeluknya.

Statemen itu adalah bagian dari bahasa dan publikasi dunia yang begitu besar dan secara hegemonik menentukan degradasi komunitas dan Negara muslim yang diposisikan secara peyoratif sebagai teroris, atau paling tidak tak memberi kepemihakan terhadap upaya war on terrorism itu. Jika sedikit jeli banyak catatan yang dapat diakses untuk mengetahui data yang diperlukan.

- Pada abad 19 kita pastilah akan susah untuk mendapatkan data bahwa muslim adalah teroris.

- Pada tahun 1881 Tsar Alexander II dicederai dalam sebuah peledakan bom dan pada kejadian itu 21 orang tewas. Belakangan diketahui bahwa pelakunya adalah Ignacy Hryniewiecki, bukan seorang muslim.

- Pada tahun 1886 sebuah bom meledak di Haymarket Square, Chicago pada saat konflik perburuhan. Dua puluh orang meninggal yang salah satu di antaranya ialah seorang petugas kepolisian yang meninggal setelah dilarikan ke rumah sakit.

Bagaimana pada abad 20?

- Pada tanggal 6 September 1901, Presiden Amerika Serikat William McKinley melambaikan tangan pada Pameran Pan-Amerika di Buffalo, New York, ketika seorang anarkis berusia 28 tahun bernama Leon Czolgosz mendekatinya dan 
mengarahkan dua tembakan ke dadanya. Sebelum roboh, Presiden ini mengatakan "hati-hati memberitahu kejadian ini kepada istri saya." Leon, pembunuh sang Presiden, bukan seorang muslim.

- Tanggal 1 Oktober 1910 ada ledakan bom di gedung surat kabar Time, Los Angeles. Dua puluh satu orang tak berdosa terbunuh. Pelakunya dua orang beragama Kristen, James dan Joseph.

- Tanggal 28 Juni 1914 Archduke of Austria dan isterinya tewas dalam pembunuhan di ibukota provinsi Austro-Hungaria dari Bosnia dan Herzegovina, oleh Gavrilo Princip, berusia 19 tahun. Anak muda ini adalah anggota Young Bosnia dan salah satu dari kelompok pembunuh terorganisir dan dipersenjatai oleh Black Hand. Hal ini menyebabkan Blok Sentral (termasuk Jerman dan Austria-Hungaria) dan sekutu Serbia menyatakan perang terhadap satu sama lain, mulai Perang Dunia. Gavrilo Princip bukan seorang muslim.

- Tanggal 19 April 1925 terjadi ledakan bom di gereja St.Negelya, Sofia, ibukota Bulgaria. Ratusan meninggal dalam kejadian itu, di samping yang luka-luka, yang menyebabkannya dicatat sebagai kejadian pembunuhan terbesar di Negara itu, dan pelakunya ialah partai komunis. Tak satu pun di antara pelakunya beragama Islam.

- Tanggal 9 Oktober 1934 King Alexander I Yugoslavia terbunuh dengan sebuah tembakan oleh Vlada Georgieff, bukan seorang muslim. Pembajakan pertama pesawat terbang bukan oleh seorang atau sekelompok muslim.

- Pada tanggal 1 Mei 1961 pesawat milik Amerika Serikat. Pelakunya ialah Ramirez Ortiz, bukan muslim.

- Seorang non muslim pada tanggal 28 Agustus 1968 juga tercatat membunuh Duta Besar Amerika Serikat untuk Guatemala.

- Pada tanggal 30 Juli 1969 Duta besar Amerika Srikat untuk Jepang juga terbunuh dengan bersenjatakan sebilah pisau, oleh seorang berkewarganegaraan Jepang, non muslim.

- Tanggal 3 September 1969, Duta Besar Amerika Serikat untuk Brazil diculik. Bukan oleh seorang muslim.

- Tanggal 19 April 1995 Gedung Federal di Oklahoma dibom dengan menggunakan sebuah truk. Ratusan orang tewas, dan pelakunya bukan muslim. Tetapi pemberitaan yang mengemuka pada media selama berhari-hari ialah "middle east conspiracy". Belakangan diketahui pelakunya adalah Timothy dan Terry, anggota gerakan sayap kanan. Bukan muslim.

- Rentang waktu antara 1941 hingga 1948 usai perang dunia II, 259 kali serangan teroris dilakukan oleh teroris Jahudi.

- Pada tanggal 22 Juli 1946 bom yang diledakkan di Hotel King David di Jerusalem dilakukan oleh geng teroris bernama Irgun bekerja sama dengan geng Stern yang dikenal memiliki hubungan manajemen khusus di bawah arahan Managem Begin, dengan korban 91 orang termasuk tokoh Desir Yassin. Dikhabarkan bahwa mantan Perdana Menteri Shamir juga pernah menjadi anggota Irgun dan kemudian pindah ke Stern yang dikenal memang lebih radikal. Tetapi bom itu diasosiasikan dengan pekerjaan muslim. Dua tahun kemudian, dia menjadi Perdana Menteri Israel. la juga kemudian menjadi penerima hadiah Nobel perdamaian. Bayangkanlah itu. Sebelum 1945 Israil tidak akan ditemukan dalam peta. Para teroris itulah yang membangunnya. 
- Di Jerman antara tahun 1968 sampai 1992, geng bernama Baader Meinhoff membunuh sejumlah orang tak berdosa. Brigade Merah di Italia melakukan pembunuhan-pembunuhan atas sejumlah orang tak berdosa, juga menculik dan setelah 5 hari kemudian membunuh Aldo Moro, mantan perdana menteri Italia.

- Maret 1995, tepatnya tanggal 20 Aum Shinrikyo, sebuah sekte Budha dari Jepang menimbulkan kehebohan berskala internasional, ketika beberapa anggotanya melaksanakan serangan gas sarin di kereta bawah tanah Tokyo. Teror ini menewaskan 12 orang, membuat 54 orang sakit parah, serta memengaruhi lebih dari 980 orang. Banyak pula korban yang enggan untuk mengungkapkan diri, sehingga angka pasti jumlah korban sulit didapatkan.

- Di Inggeris terdapat sebuah tentara separatis bernama Irish Republican Army (IRA) yang sejak seratus tahun lalu melakukan kekerasan-kekerasan dengan korban yang besar. Mereka beragam Katholik dengan perjuangan yang ideologis, namun ini tak mengemuka dalam pemberitaan media.

- Tahun 1991 IRA juga membom kantor BBC, tetapi media ini tidak menyebut kaiannya dengan Katholik. Mengapa Tony Blair lebih takut kepada teroris mulim disbanding teroris Katholik yang sudah terbukti melakukan kekerasan selama seratus tahun belakangan?

- Di Spanyol dan Perancis, Euskadi Ta Askatasuna (ETA), sebuah kelompok gerakan separatis bersenjata tercatat melakukan ratusan kali terror dengan jumlah korban yang juga begitu besar, sejak tahun 1961 hingga 2011.

- The Lord's Resistance Army (LRA), yang juga dikenal dengan nama Lord's Resistance Movement, adalah sebuah kelompok pemberontak sekte heterodox Christian yang beroperasi di Uganda bagian Utara, Sudan Selatan dan Republik Afrika Tengah dan Republik Demokratik Kongo. Mereka melatih anak-anak untuk melakukan teror. Tetapi begitulah dunia tidak menyebutnya sebagai apa adanya.

- Di Sri Langka ada Liberation Tigers of Tamil Eelam (LTTE) atau yang di Indonesia lebih dikenal dengan nama Macan Tamil. la adalah suatu gerakan insurgensi yang berbasiskan etnis, bertujuan mendirikan Negara Tamil yang independen di Tenggara Sri Lanka. Sejak dibentuk pada tahun 1976 oleh Velupillai Prabhakharan telah melancarkan gerakan-gerakan gerilya melawan pemerintah Sri Lanka. Gerakan teror ini lebih terkenal karena divisi bom bunuh dirinya bernama Macan Hitam yang dibentuk pada tahun 1987 dan telah melancarkan ratusan aksi bom bunuh diri (termasukpembunuhan Perdana Menteri India, Rajiv Gandhi). Mereka Hindu. Kapan pernah Hindu dikaitkan dengan teror oleh opini internasional?

- Di India yang majemuk itu, boleh dikatakan hampir semua kelompok agama termasuk kelompok komunis memiliki organisasi teroris dengan catatan-catatan kekerasan menewaskan banyak nyawa orang tak berdosa yang mengerikan. Tetapi tak begitu menarik bagi media untuk menelisiknya sebagai teror berdasarka ideologi dan agama yang mencemaskan dunia. Ketika muncul sebagai newsbrief di halaman media (tidak menjadi headline), sangat berbeda jika ada kejadian kekerasan ketika di mana-mana dikaitkan dengan muslim.

Siapakah manusia paling bengis di dunia sepanjang sejarah yang pernah membunuh banyak orang?Tentulah kita akan menyebut Hitler yang membunuh 6 juta Jahudi. Itu 
belum termasuk korban pada perang dunia kedua lainnya. Siapa dia? Dia orang Kristen.Joseph Stalin adalah salah satu dari tujuh anggota pertama Politbiro, yang didirikan pada tahun 1917 untuk mengelola Revolusi Bolshevik, bersama Lenin, Zinoviev, Kamenev, Trotsky, Sokolnikov dan Bubnov. Tokoh besar komunis ini menewaskan antara 20 sampai 60 juta jiwa dalam sejarah Rusia. Di China, Mao Tse Tung tercatat menewaskan paling sedikit 14 juta jiwa. la non muslim. Benito Musollini menewaskan 400 ribu jiwa. la bukan muslim.

Selama revolusi Francis Maximilin Robespierre bertanggung jawab atas tewasnya 200.000 jiwa. Ashoka dalam salah satu pertempuran Kalinnga tercatat membunuh 100.000 jiwa. Dia orang Hindu. Kita akan mencatat secara adil Saddam Husein yang menewaskan 100.000 ribu jiwa, namun itu semua harus dikaitkan dengan embargo Barat dan Geroge Bush yang membunuh lebih dari setengah juta anak-anak di Irak.

Banyak orang mengklaim tewasnya 500.000 orang era Soeharto, tetapi ini tak mungkin dibandingkan dengan Stalin, Hitler dan Mao.

Anda tak akan mengatakan Soeharto itu muslim fundamentalis, ekstrimis atau teroris sebagaimana kolonial Belanda menuduh Si Pitung dan Jiih (Betawi) dan Naga Bonar (Sumatera Utara).

Proyeksi Pewr Research Center penduduk dunia sekitar tahun 2050 akan terdiri dari 31,4 \% Kristen, 29,7 \% muslim, 13,2\% orang yang patut disebut tak berafiliasi agama, $14,9 \%$ Hundu, 5,2 \% Budha, 4,8\% beragama suku, 0,7\% agama-agama lainnya, dan $0,2 \%$ Jahudi.Proyeksi ini menunjukkan kemajuan pesat populasi umat Islam.

Pada tahun 2013 Pew Research Centre juga melaporkan hasil survey yang menunjukkan keinginan besar untuk menarapkan hukum syariah (dalam bidang rukun keluarga, hukuman untuk kriminal dan eksekusi bagi murtad) di sejumlah negara. Angka-angka pro syari'ah dilaporkan demikian: Afganistaan dan Iraq di atas $90 \%$, Banglades, Maroko, Pakistan dan Palestina di atas $80 \%$, Jordania, Indonesia, Mesir di atas 70\%, Tunisia 56\%, Azerbayzan 8\%, Kazakhstan 10\%, Turki dan Albania12 \%, Bosnia 15\%, Kosovo 20 \%, Tajikistan 27 \%, Libanon 29 \% dan Kyrzistan 35 \%.

Dalam survei ini Pew Research Centre membedakan responden atas orang taat beribadah dan kurang taat beribadah. Artinya muslim yang tidak taat juga mendukung syariah dalam temuan survei ini.

Dukungan terendah untuk sejumlah rangan seperti Prostisusi (91\%) ada di Afrika SubSahara, untuk homoseksualitas ada di Timur tengah non Afrika (79\%), bunuh diri (80 $\%)$ di kawasan Asia Tengah, seks di luar nikah dan minuman Alkohol di Eropa Timur (67\%), aborsi (61\%) di Asia Tengah dan Eutanasia (62\%) juga di Asia Tengah.

Saya percaya MC Bassiouni (Emeritus Professor of Law dari DePaul University 19642012) yang menegaskan bahwa mendefinisikan terorisme yang tak ambigu dan memuaskan setiap orang, adalah sebuah ketak-mungkinan. Hal itu disebabkan oleh perbedaan fundamental values yang berbenturan antara satu dan lain orang, antara satu dan lain bangsa, dan antara satu agama dengan lain dalam menilai tindakan kekerasan itu. 
Saya juga percaya bahwa semua yang disebut terorisme itu adalah perang non-official dan jika dibandingkan dengan banyak perang yang tercatat dalam sejarah, sangat tidak bermakna baik dilihat dari aspek korban maupun akibatnya bagi kehidupan manusia. Memang agak sinis, tetapi Professor Johnson (Rutgers University) sangat tepat menyebut terorisme itu just another war.

Mitologi Afrika mengenal 6 dewa perang, Mesir 14, Cina 6 (utama) dan ratusan dewa perang lainnya, Greek 25, Roma 9 perang, Hindu 30, Jepang 8, dan Semitik 7. Selain itu, susah menyebut perang-perang lebih besar yang hadir atas nama hegemoni dalam sejarah tidak terkait dengan gosple, glory dan gold.

- Antara 3 sampai 15 juta tercatat tewas karena Thirty Years' War yang dilaksanakan atasnama Holy Roman Empire (1618-1648), dan itu perang atas nama agama (Katholik vs Protestan). Jumlah korban itu mencapai $0.5 \%-2.1 \%$ dari penduduk dunia saat itu.

- Antara 2 hingga 4 juta (0.4\%-0.8\% dari penduduk dunia saat itu) telah tewas dalam perang agama antara Katholik dan Protestan di Perancis (1562-1598).

- Serbuan Kristen terhadap Islam dalam perang Salib telah menewaskan antara 1 hingga 3 juta jiwa (1095-1291) yang kurang lebih jumlah itu kira-kira dapat setara dengan $0.3 \%-2.3 \%$ dari penduduk dunia saat itu.

- Antara 1 hingga 2 juta tewas dalam Perang Sipil Sudan II (1983-2005). Ini perang agama antara Kristen.

- Catatan sejarah dunia juga menyebut antara 130 ribu hingga 250 ribu tewas dalam perang Sipil Libanon yang terjadi antara tahun 1975 hingga 1990. Sunni, Syiah, Jahudi, Druze dan Kristen terlibat di dalamnya.

Islam mendapat kesulitan karena opini dunia menyudutkannya. Itu juga terjadi di Indonesia. Jaringan internasional digalang, dan sebagian menjadi urusan yang sangat menyayat hati di Negara-negara pengikut seperti Indonesia. War on terrorism itu tercatat kian gencar pasca seragan 911.

Padahal dari 38 video beredar tentang itu terbuktikan bahwa kebohongan telah dipakai untuk menyudutkan Islam. Tak mungkin pesawat terbang dengan bahan utama aluminium bisa menembus konstruksi baja gedung WTC. Tidak mungkin ketinggian gedung yang mesti dilewati sebelum menabrak WTC dapat memperkenankan sebuah pesawat terbang menembus WTC sebelum merobohkan gedung yang menghadang pada jarak yang lebih dekat. Tetapi ini sudah menjadi opini dunia.

\section{Siyono meninggal}

Densus 88 digugat. Muhammadiyah menuntut keadilan. Muhammadiyah pro teroris? Tidak begitu. Muhammadiyah menuntut Pancasila sebagai dasar bagi pelaksanaan perang terhadap teroris dan wajib dilakukan komprehensif. Muhammadiyah menganggap Negara RI yang dimerdekakan tanggal 17 Agustus 1945 dengan ideologi Pancasila dan dengan faham NKRI adalah sebuah Negara ahdi (Kesepakatan). Muhammadiyah yakin dan bersyahadah (bersaksi) bahwa dengan Pancasila itu Indonesia bisa dibikin lebih baik atas komitmen bersama dan usaha bersama serta 
tekun dan jujur mencegah kemungkaran agar terwujud cita-cita baldatun thayyibatun wa rabbun ghafur.

Jangan sekali-sekali menyudutkan Islam Indonesia yang andilnya sangat-sangat besar itu, dengan isyu teroris yang dikendalikan asing. Itu harapan dan permintaan Muhammadiyah.

Shohibul Anshor Siregar Naskah ini pertamakali diterbitkan oleh Harian Waspada Medan, Senin, 11 April 2016, hlm B7 